\title{
Persoonia pauciflora (Proteaceae), a new species from the Hunter Valley, New South Wales
}

\author{
Peter H. Weston
}

\begin{abstract}
Weston, Peter H. (National Herbarium of New South Wales, Royal Botanic Gardens, Sydney, NSW 2000, Australia) 1999. Persoonia pauciflora P.H. Weston (Proteaceae), a new species from the Hunter Valley, New South Wales. Telopea 8(2): 159-164. Persoonia pauciflora P.H. Weston, a new species from the Hunter Valley, New South Wales, is described and distinguished from its closest relatives. The keys to Persoonia that have been published recently in the Flora of New South Wales and Flora of Australia are amended to include this species.
\end{abstract}

\section{Introduction}

In September 1997 Gordon Patrick, of Ecotone Ecological Consultants, collected a specimen of an unusual Persoonia near North Rothbury in the Hunter Valley, New South Wales, while conducting a flora survey. This specimen turned out to belong to a rare, unnamed species, which had not previously been collected. It is described in this paper, using the descriptive terminology discussed by Weston (1994), amended as discussed below.

\section{New descriptive terminology}

In previous publications (Weston 1994, Weston \& Johnson 1991, 1994, 1997), the tips of the tepals in Persoonia were described as frequently being acuminate or mucronate to caudate. These mucros or tails are apparently present, at least as vestiges, in most species of the subfamily Persoonioideae. They are usually coherent in bud, but in some species (e.g. P. myrtilloides — see Douglas \& Tucker 1996: fig. 25) they are free in bud, occupying an apparently subterminal position on the abaxial tepal surface. In such cases they are most easily observed as a 'crown' of four points or tails on the tip of the flower bud. Douglas and Tucker (1996), in their detailed study of floral organogeny in the Persoonioideae, suggest that tepal mucros in the subfamily could be the residual apices of the tepal primordia. Douglas and Tucker use the German term 'Vorläuferspitze' for this type of structure, apparently on the basis of priority, but I have used 'terminal points' instead.

\section{Taxonomy}

Persoonia pauciflora P.H. Weston, sp. nov.

Frutex patulus. Pili $0.05-0.7 \mathrm{~mm}$ longi, adpressi vel antrorse patentes. Folia linearia, filiformia, acuminata, (0.3-)1.7-3.5 cm longa, (0.4-)0.6-0.8 mm lata, teretia ubi viva, subteretia, infra canaliculata ubi siccata, incurva. Inflo rescentia auxotelica, 1-9 floribus; rhachis $0-0.9 \mathrm{~cm}$ longa. Flores regulares. Pedicelli $0.7-2.0 \mathrm{~mm}$ longi, moderate pubescentes. Tepala 4.5-5.0 $\mathrm{mm}$ longa. Antherae sine appendice. Ovarium glabrum. Ovulum unicum. 
Holotype: New South Wales: North Coast: North Rothbury area, P.H. Weston $2084 \mathcal{E}$ G. Patrick, 16 Jan 1998 (NSW 415790). Isotypes: CANB, K, MEL, MO.

Spreading, apparently non-lignotuberous shrubs, 0.4-1.4 $\mathrm{m}$ high, 0.4-2.0 $\mathrm{m}$ wide; bark smooth, grey. Hairs $0.05-0.7 \mathrm{~mm}$ long, greyish, mostly antrorsely appressed but a minority being antrorsely spreading. Immature stems moderately hairy; internodes $0-7(-14) \mathrm{mm}$ long. Leaves alternate, linear-filiform, acuminate, $(0.3-) 1.7-3.5 \mathrm{~cm}$ long, (0.4-)0.6-0.8 mm wide, terete when living, compressed and grooved underneath when dried, spreading to suberect and usually slightly to moderately incurved, \pm laterally symmetrical, not twisted, not pungent, bright green when fresh, olive green when dried, concolorous, sparsely to moderately hairy when immature, sparsely hairy to glabrescent when mature, smooth; venation obscure. Inflorescences growing from terminal or lateral buds, auxotelic, 1-9-flowered; rachis 0-0.9 cm long; flowers mostly subtended by reduced leaves but more distal flowers in an inflorescence sometimes subtended by full-sized leaves. Pedicels $0.7-2.0 \mathrm{~mm}$ long, antrorsely spreading, moderately hairy, green when living. Perianth actinomorphic, the tepals $4.5-6.0 \mathrm{~mm}$ long, acute, not keeled, moderately hairy on the abaxial surface, dull yellow; terminal points $0-0.1 \mathrm{~mm}$ long. Anthers lacking appendages, held close to one another and to the gynoecium at their bases but recurved at the tips, dull yellow; loculi $2.0-2.5 \mathrm{~mm}$ long. Gynoecium straight, 4.0-5.5 mm long; ovary glabrous; ovule 1. Drupes dull green or green with reddish purple striations, glabrous; pyrene broad-obovoid to broad-ellipsoid, 9.4-11.1 mm long, 4.6-5.5 mm wide. Seed 1; cotyledons 4-7 (Fig. 1).

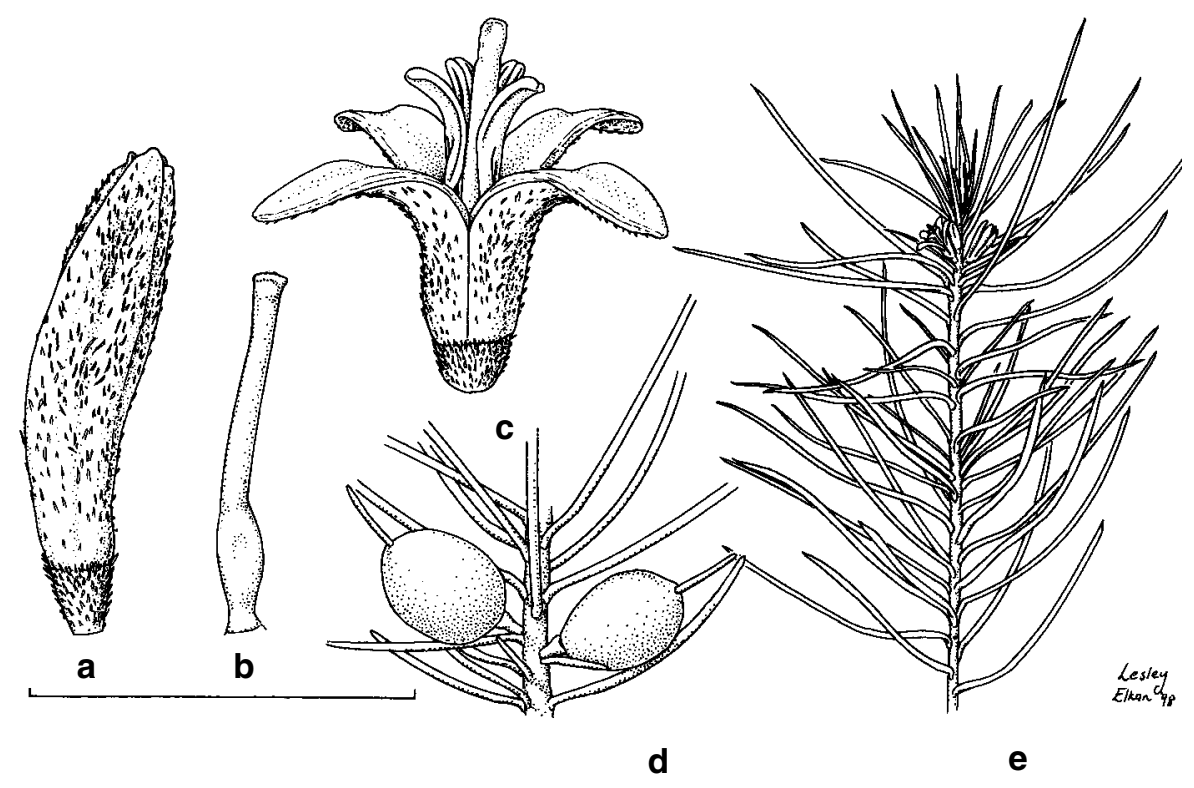

Fig. 1. Persoonia pauciflor $a$. $\mathbf{a}$, flower bud; $\mathbf{b}$, gynoecium; $\mathbf{c}$, flower; $\mathbf{d}$, fruit; e, flowering shoot. $\mathrm{a}, \mathrm{b}$ from Weston 2084 E Patrick; c, e from Weston 2083 E Patrick; d from Jobson 5030 \& Weston. Scale bar: a, b, c = $5 \mathrm{~mm}$; $\mathrm{d}=30 \mathrm{~mm} ; \mathrm{e}=40 \mathrm{~mm}$. 
Derivation of epithet: Latin paucus, few and flos, flower; referring to the few-flowered inflorescences, which distinguish this species most readily from its closest relatives.

Flowering period: collected in flower only in January, but observed in flower as late as April (G. Patrick, pers. comm.).

Habitat: dry sclerophyll forest dominated by Eucalyptus fibrosa, E. moluccana, E. punctata, and Corymbia maculata and with scattered trees of E. crebra, E. tereticornis, with an open understorey of grasses and other herbs and scattered shrubs, on clay soils derived from silty sandstones of the Farley Formation (McClung 1980), at 50-60 $\mathrm{m}$ altitude.

Distribution: known from only one population of about 60 plants, all of which occur within $1 \mathrm{~km}$ of the type locality (Fig. 2).

Proposed conservation status: geographically restricted, endangered, not conserved (2E coding of Briggs \& Leigh 1996). Clearing, habitat fragmentation, and increased vandalism resulting from land development are the most obvious threatening processes that endanger this species. P. pauciflora is known only from roadside verges and private land in a moderately disturbed rural area. Land use in the area is dominated by viticulture, small-scale farming and underground coal mining, forming a mosaic of cleared blocks and variously disturbed patches of native forest. About 26 of the 66 known adult plants occur on a block of land for which development approval

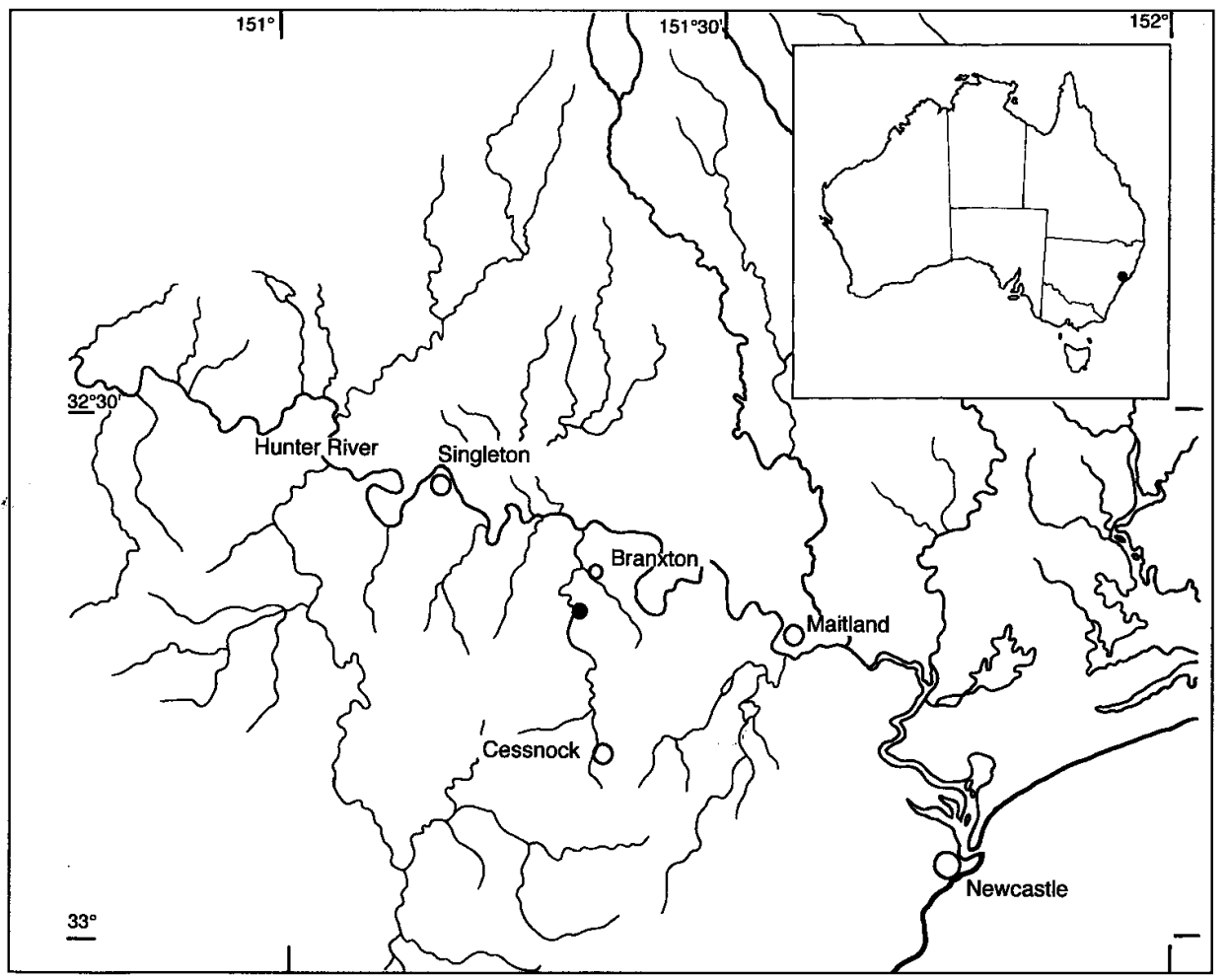

Fig. 2. Distribution of Persoonia pauciflora $(\bullet)$ shown on a 1:1000 000 map of the lower Hunter River Valley and (inset) on a map of Australia. 
had already been granted when flowering material of the species was first collected. This block has been subdivided into residential lots, each of which is covered by a covenant protecting all known plants of $P$. pauciflora. The covenant requires, for example, that each plant of $P$. pauciflora be enclosed within a protective fence of dimensions at least $6 \times 6 \mathrm{~m}$. It remains to be seen whether these measures succeed in maintaining or increasing the number of reproductively mature individuals on this land. In the meantime, a more detailed survey of the distribution of P. pauciflora is needed. High priority should also be given to propagating a sample of existing plants, with a view to introducing this species into a protected patch of native forest in the area.

Notes: $P$. pauciflora most closely resembles $P$. isophylla, and, to a lesser extent, $P$. pinifolia, which are probably its closest relatives. Terete, linear-filiform leaves that become grooved underneath on drying, is a potential synapomorphy (sensu Hennig 1966) shared by these three species. However, other taxa in Persoonia, such as P. subtilis, P. fastigiata, P. curvifolia, P. mollis subsp. livens, P. mollis subsp. leptophylla, and P. chamaepitys, also have leaves that resemble those of $P$. pauciflora in these respects. However, these taxa appear, on the basis of other characters, to be more closely related to other, widerleaved taxa.

P. pauciflora is most easily distinguished from its closest relatives by its inflorescence, which is fewer-flowered, and shorter than in P. isophylla (inflorescence (1-)10-70flowered, with rachis (0-)0.5-9 cm long) and P. pinifolia (inflorescence 30-200-flowered, with rachis $3.5-26 \mathrm{~cm}$ long). It also differs from $P$. isophylla in having shorter trich o mes (0.1-1.4 mm long in P. isophylla - twice as long on average as in P. pauciflo $\mathrm{ra}$ ), shorter terminal points on the tepals $(0.2-0.9 \mathrm{~mm}$ long in $P$. isophylla) and in not showing a tendency for the leaves to be recurved towards their tips (most leaves in P. isophylla are distinctly recurved). P. pauciflora also differs from P. pinifolia in having auxotelic inflorescences in which the subtending leaves become longer distally (anauxotelic in P. pinifolia, with the subtending leaves becoming shorter distally), shorter leaves (3-7 cm long in P. pinifolia), and shorter trichomes (0.1-1.3 $\mathrm{mm}$ long in P. pinifolia).

Flower size also distinguishes existing collections of P. pauciflora (tepals 4.5-6.0 mm long) from $P$. isophylla (tepals 7-8 $\mathrm{mm}$ long) and P. pinifolia (tepals 8-9 $\mathrm{mm}$ long). However, all of the existing flowering specimens of $P$. pauciflora were collected in January 1998, after several months of low rainfall, and many of the flower buds had withered before maturing. It is possible that this apparent size difference reflects adverse environmental conditions at North Rothbury during the summer of 1997-98, and that it will not be maintained once flowering material of P. pauciflora has been collected in subsequent summers.

The habitat of $P$. pauciflora is distinctly different from that of both $P$. isophylla and $P$. pinifolia, which grow exclusively on soils derived from Hawkesbury Sandstone. The plant communities to which $P$. isophylla and P. pinifolia belong usually have a much denser, more diverse shrubby component than that in which P. pauciflora grows. Only a few ecologically tolerant species, such as Persoonia linearis, are shared by the habitats of P. isophylla and P. pinifolia on the one hand, and P. pauciflora on the other.

Selected specimens (8 collections examined): New South Wales: North Coast: North Rothbury, $15 \mathrm{~km}$ N of Cessnock, G. Patrick s.n., Sep 1997 (NSW 419768); $0.1 \mathrm{~km} \mathrm{SW}$ of junction of Branxton Road and Tuckers Lane, North Rothbury, 18 km N of Cessnock, 32 ${ }^{\circ} 41^{\prime} 34^{\prime \prime S} 151^{\circ} 20^{\prime} 25^{\prime \prime} E$, P.C. Jobson 5030 \& P.H. Weston,18 Oct 1997 (NSW 415973). 


\section{Amendments to published keys to Persoonia}

The keys published by Weston $(1991,1995)$ need to be altered to accommodate P. pauciflora. In both keys, a couplet is reached where neither lead is consistent with material of P. pauciflora - in Weston (1991) at Group 1, couplet 4, and in Weston (1995) at couplet 53. This part of both keys can be improved, incorporating P. pauciflora, by altering several couplets, as follows:

A Leaves 3.0-7.0 cm long; inflorescences anauxotelic, with flower-subtending leaves mostly much shorter than sterile leaves and progressively becoming shorter distally P. pinifolia

A* Leaves 1.0-3.5 cm long; inflo rescences auxotelic, with flower-subtending leaves mostly the same length as sterile leaves, or, if mostly shorter, then progressively becoming longer distally

B Leaves terete or subterete and grooved underneath when living, subterete and g rooved underneath when dried

C Leaves $0.8 \mathrm{~mm}$ wide or more; leaf tip truncate to acute; ovules 2 .... P. mollis

$C^{*}$ Leaves $0.8 \mathrm{~mm}$ wide or less; leaf tip acuminate; ovule 1

D Inflo rescences 1-9-flowered; rachis 0-0.9 cm long; leaves incurved

P. pauciflor a

D*Inflorescences (1-)10-70-flowered; rachis (0-)0.5-9 cm long; leaves recurved towards their tips P. isophylla

$\mathrm{B}^{*}$ Leaves subterete and shallowly concave above when living, subterete and grooved above when dried

E Tepals with free apical points, forming a prominent 'crown' at the tip of the flower bud; leaves c. $0.5 \mathrm{~mm}$ wide

P. acerosa

$E^{*}$ Tepals with coherent apical points, not prominently distinct from the rest of the tepal; leaves $0.3-0.5 \mathrm{~mm}$ wide P. tenuifolia

\section{Acknowledgments}

Gordon Patrick provided helpful comments on the manuscript and assistance in the field. Christopher Richards encouraged me to study the plants growing on his land. Peter Jobson and Graeme Errington provided technical assistance. Karen Wilson helped in preparing the Latin description. Lesley Elkan drew the figures. Joy Everett, Karen Wilson and Peter Wilson provided helpful comments on an earlier draft of the manuscript.

\section{References}

Briggs, J.D. \& Leigh, J.H. (1996) Rare or Threatened Australian Plants, 1995 revised edition. (CSIRO: Collingwood).

Douglas, A.W. \& Tucker, S.C. (1996) Comparative floral ontogenies among Persoonioideae includingBellendena (Proteaceae). Amer. J. Bot. 83: 1528-1555.

Hennig, W. (1966) Phylogenetic Systematics. (University of Illinois Press: Urbana).

McClung, G. (1980) Permian marine sedimentation in the northern Sydney Basin. Pp. 55-72 in Herbert, C. \& Helby, R. (eds) A Guide to the Sydney Basin. (Government Printer: Sydney). 
Weston, P.H. (1991) Persoonia. Pp. 4-19 in Harden, G.J. (ed.), Flora of New South Wales, vol. 2.

(New South Wales University Press: Kensington).

Weston, P.H. (1994) The Western Australian species of Persooniinae (Proteaceae). Telopea 6: 51-165.

Weston, P.H. (1995) Persoonia. Flora of Australia 16: 50-125.

Weston, P.H. \& Johnson, L.A.S. (1991) Taxonomic changes in Persoonia (Proteaceae) in New South Wales. Telopea 4: 269-306.

Weston, P.H. \& Johnson, L.A.S. (1994) Three new species of Persoonia (Proteaceae) from Queensland. Telopea 6: 31-37.

Weston, P.H. \& Johnson, L.A.S. (1997) Persoonia hindii (Proteaceae), a new species from the Newnes Plateau, New South Wales. Telopea 7: 199-203.

\section{Manuscript received 10 September 1998 \\ Manuscript accepted 20 January 1999}

\section{Note added in proof}

After this paper had been accepted for publication, Gordon Patrick discovered about 180 additional plants of Persoonia pauciflora, from one of which he collected a specimen (NSW 426889). All of these plants occur within $1 \mathrm{~km}$ of the type locality, and bring the total number of known adult individuals to about 250. The new specimen confirms my suggestion (p. 162), that flowers collected in 1998 were unusually small, and also provides additional information on flowering period and habitat. Consequently, the description needs to be amended as follows:

Inflorescence rachis $0-1.1 \mathrm{~cm}$ long. Pedicels $0.7-2.5 \mathrm{~mm}$ long. Tepals $4.5-8.0 \mathrm{~mm}$ long. Anther loculi 2.0-4.0 mm long. Gynoecium 4.0-7.0 $\mathrm{mm}$ long.

Flowering period: collected in flower from January to April, but probably flowering as late as May.

Habitat: dry sclerophyll forest or woodland dominated by Corymbia maculata and one or more of the following species: Eucalyptus fibrosa, E. moluccana, E. punctata, E. crebra, E. tereticornis and E. capitellata; understorey shrubby, or open, with grasses and other herbs and scattered shrubs; on clay soils derived from silty sandstones of the Farley Formation (McClung 1980), at 50-70 m altitude.

Distribution: known from only one population of about 250 plants, all of which occur within $1 \mathrm{~km}$ of the type locality (Fig. 2).

Additional specimen: New South Wales: North Coast: Between Tuckers Lane and Littlewood Road, North Rothbury, 3241'45"S 151'20'45"E, G. Patrick, 14 Apr 1999 (NSW 426889). 